\title{
Water-Isotope Capacity Building and Demonstration in a Developing World Context: Isotopic Baseline and Conceptualization of a Lake Malawi Catchment
}

\author{
Limbikani C. Banda ${ }^{1, *}$, Michael O. Rivett ${ }^{2}$, Robert M. Kalin ${ }^{2}{ }^{\oplus}$, Anold S.K. Zavison ${ }^{1}$, \\ Peaches Phiri ${ }^{1}$, Laura Kelly ${ }^{2}$, Geoffrey Chavula ${ }^{3}$, Charles C. Kapachika ${ }^{4}$, Macpherson Nkhata ${ }^{1}$, \\ Sydney Kamtukule ${ }^{1}$, Prince Mleta ${ }^{1}$ and Muthi Nhlema ${ }^{5}$ \\ 1 Ministry of Agriculture, Irrigation and Water Development, Private Bag 390, Lilongwe 3, Malawi; \\ anoldzavison@gmail.com (A.S.K.Z.); peachesphiri@gmail.com (P.P.); macpherson.nkhata@gmail.com (M.N.); \\ slkamtukule@gmail.com (S.K.); princemleta@gmail.com (P.M.) \\ 2 Department of Civil \& Environmental Engineering, University of Strathclyde, Glasgow G1 1XJ, UK; \\ michael.rivett@strath.ac.uk (M.O.R.); robert.kalin@strath.ac.uk (R.M.K.); laura.kelly.100@strath.ac.uk (L.K.) \\ 3 Department of Civil Engineering, University of Malawi-The Polytechnic, P/B 303, Blantyre 3, Malawi; \\ gchavula@gmail.com \\ 4 Department of Land Surveying, University of Malawi-The Polytechnic, P/B 303, Blantyre 3, Malawi; \\ ckapachika@poly.ac.mw \\ 5 BASEflow, 2nd Floor, Galaxy House, P.O. Box 30467, Chichiri, Blantyre 3, Malawi; muthi@baseflowmw.com \\ * Correspondence: limbikanicbanda@gmail.com
}

Received: 12 October 2019; Accepted: 6 December 2019; Published: 10 December 2019

check for updates

\begin{abstract}
Developing countries such as Malawi require improved access to isotope tracer tools to better characterize and manage water resources threatened by land development, deforestation and climate change. This is the first published study to use an isotope facility developed in Malawi for this purpose, instead of relying upon sample analyses from abroad. Results from this new facility are used to evaluate an important Lake Malawi catchment in the Rift Valley. This work successfully established a stable-isotope baseline, hydrochemical signatures, and system conceptualization against which future policy change and management strategies may be measured. Precipitation isotopic composition was consistent with the Global Meteoric Water Line, but varied, confirming different precipitation systems nationally. Groundwater largely followed a Local Meteoric Water Line, with limited isotopic variation indicating predominant areal groundwater recharge, but with dry-season evaporative enrichment of groundwater near Lake Malawi. Surface-water isotopes widely varied with local precipitation, suggesting the latter accounted for wet-season river flows, but upstream dambo (complex wetlands occupying a shallow, seasonal waterlogged depression) helped sustain dry-season flows. Isotope capacity reinforced water-resource conceptualization and provenance in a hydrologically complex, but not atypical, Rift Valley system, exhibiting a noted complexity of groundwater-surface-water interactions. The latter, critical to integrated water resource management, requires more focused study, to which an expanded array of isotopes will contribute to tracking Sustainable Development Goal 6 targets. This study and future catchment studies should help underpin Malawian water-resource policy implementation on several identified fronts.
\end{abstract}

Keywords: isotope tracers; stable isotopes; groundwater; SDG 6 (sustainable development goal 6); integrated water resource management (IWRM); conceptual model; Malawi 


\section{Introduction}

Water-isotope tracing is a powerful tool for conceptualizing hydrological-hydrogeological systems [1-3], including the characterization of hydrological conditions, flow-system evolution, groundwater-surface-water exchange, groundwater recharge and water-source provenance [4-7]. The repertoire of isotope tracers continues to grow, offering increasing insight and versatility [8-11]. As such, isotopes increasingly underpin integrated water resources management (IWRM) [12-14]. Their potential to help strategically address Millennium, and now Sustainable Development, Goals (M/SDGs) in the developing world, remains not fully realized.

Several issues conspire to create this shortfall. Access to in-house isotope analytical facilities within developing countries may be non-existent or limited, a noted issue for Africa [15]. Although there has still been significant isotopic characterization of African water resources [16], much of those isotope data have been secured through sample export and analysis and interpretation abroad $[17,18]$. This is especially true for developing countries where data can be very sparse [16] and in-house isotope capacity (both analysis and interpretative) fails to develop. The development of developing country water resources is often undertaken in isolation, rarely seeking to understand surface-water-groundwater relationships. African rural resource development has focused almost exclusively on groundwater, typically hand-pumped boreholes for communities $[19,20]$, with little perceived need for isotopes, understanding of the sustainability of the water resource at large, and system linkages.

Significant rationale exists for the uptake of isotopic tools in developing countries, and is considered for Malawi here. Groundwater development in recent decades, although significant, has not been that strategic; water points in Malawi, mostly groundwater-related rural community supplies, now approach 100,000 [21]. Surface-water resources are also prominent. Lake Malawi is African's third largest lake and contains reservoir dams on its lake tributaries, serving, for example, its capital Lilongwe, and a pipeline from the lake's sole outlet, the Shire River, serving its second city, Blantyre. Large irrigation schemes are also planned, for instance the Shire River Irrigation Project to divert $~ 5 \%$ $\left(20-50 \mathrm{~m}^{3} / \mathrm{s}\right)$ of the Shire River flow into $130 \mathrm{~km}$ of feeder canals [22]. Large lakes such as Malawi and Chilwa are internationally significant environments and of national socio-economic significance; their drainage basins and underlying aquifers, providing (dry season) baseflows, demand integrated understanding. Groundwater recharge, essential to assessing sustainable aquifer yields, is often poorly constrained [23]. Climate conditions and sources of rainfall are also complex; Malawi's Rift Valley location, with significant topographic variation, causes marked within-country contrasts. Significant land use changes, e.g., urbanization, agricultural intensification and deforestation, may influence the recharge-runoff balance and pose pollution risks. Last, but not least, climate change vulnerability is considered high [24,25], with a predicted increased severity of droughts in Southern, and floods in Northern, Malawi [26]. An arsenal of isotopic tools may contribute to understanding of these issues.

These issues provided impetus for the recent development of a national isotope facility in Malawi, and the first baseline catchment study arising from that newly developed capacity presented herein. The Government of Malawi, with funding from the International Atomic Energy Agency (IAEA) established an Isotope Hydrology Laboratory in Malawi's Ministry of Agriculture Irrigation and Water development (MoAIWD) Central Water Laboratory in Lilongwe in 2018. The IAEA also helped finance establishment of the Malawi Network of Isotopes in Precipitation (MNIP), together with foundational water resource isotope-hydrochemical surveys and capacity building supported by the Climate Justice Fund-Water Futures Programme (CJF)—a wide-ranging research initiative led by the University of Strathclyde and funded by the Scottish Government to support the Government of Malawi in meeting SDG 6. This study is the first of an initial suite of isotopic baseline hydrochemical studies aiming to improve the conceptualization and understanding of Malawi's water resources, and demonstrate the practical value of the investments in resource management.

This study focused on a catchment of the Lake Malawi Basin with contrasting geographies arising from a location at the southern extremity of the East African Rift System. The objectives of this work were to (i) establish an isotopic baseline-hydrochemical understanding against which future change 
arising from land use development and climate change may be measured; (ii) develop an integrated conceptual model of the system water resource that may underpin future IWRM; and (iii) identify areas of influence of Malawian policy implementation expected from this and its companion suite of studies on other catchments.

This study is the first to demonstrate the significance of an in-house, national isotope capacity in Malawi, a developing country ranking 170 out of 188 in the 2015 Human Development Index [27]. The study concludes that stable isotopes reinforce the process-based conceptualization of a varied water-resources, and helps confirm and provide insight into the diversity of groundwater-surface-water interaction processes. As such, the developing world vitally requires increased access to such tools.

\section{Materials and Methods}

\subsection{Study Area Setting}

\subsubsection{Water Resources}

The study area surrounds Lilongwe City and covers the Linthipe River Catchment and South West Lake Malawi River Catchment (including most of Water Resource Areas (WRAs) 3 and 4) (Figure 1). The Linthipe River is one of the major riverine inflows to Lake Malawi, Africa's second largest lake by volume and third by area, and an integral part of the international Zambezi River Basin System. The catchment contains several major storage reservoirs; the Kamuzu Dam I (of storage capacity 4.5 million $\mathrm{m}^{3}$ ) and adjacent Kamuzu Dam II $\left(18.5\right.$ million $\left.\mathrm{m}^{3}\right)$ on the Lilongwe River, and the Bwanje Valley dam (5.6 million $\mathrm{m}^{3}$ ) on the Namikokwe River. The Kamuzu dams supply the capital Lilongwe. The Bwanje Valley dam primarily serves the Bwanje Irrigation Scheme, with some water supply and hydro-power generation.

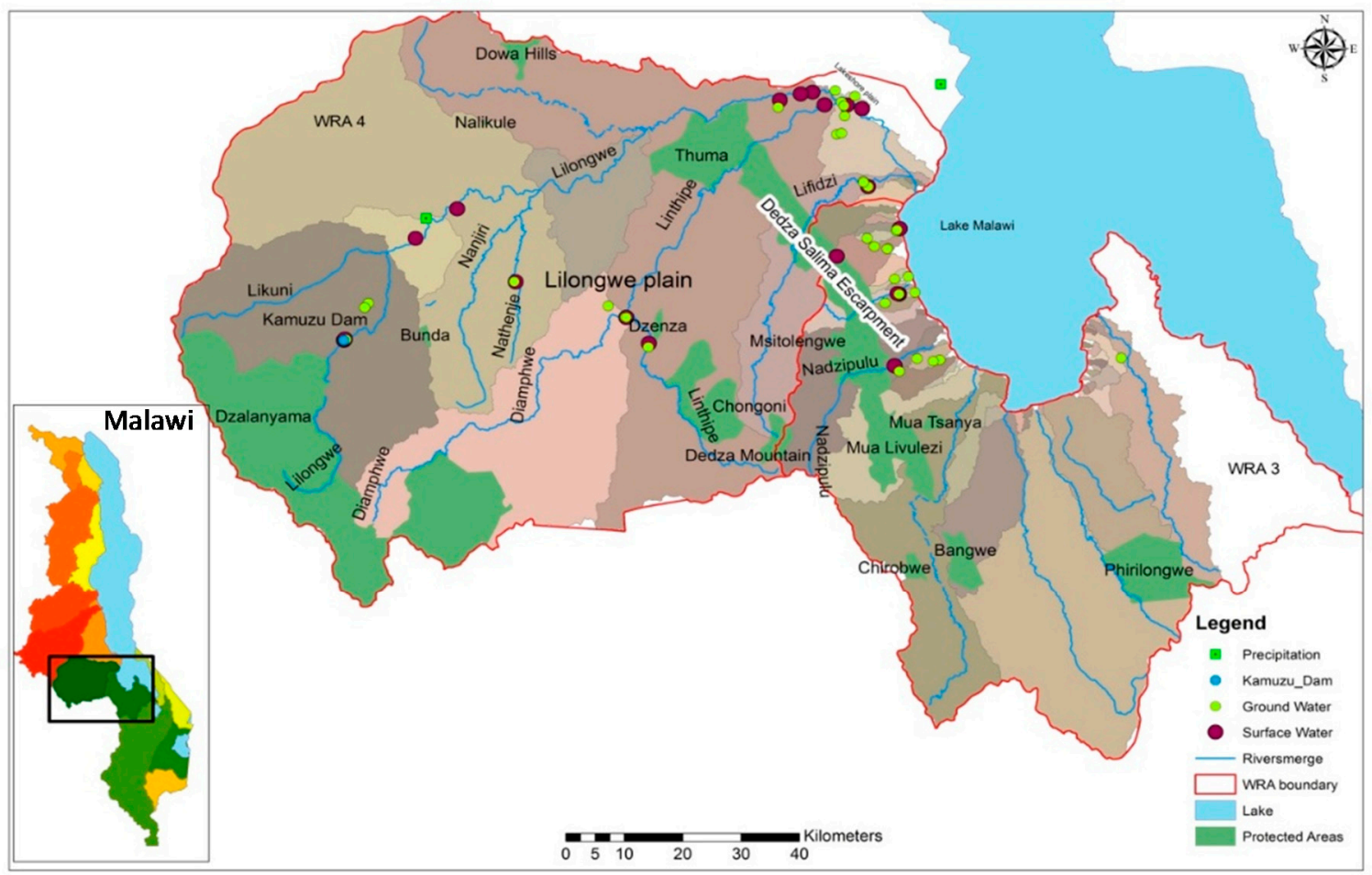

Figure 1. Study area showing surface water bodies, water resource area (WRA) catchments, river sub-catchments (variously coloured zones) and survey water-sampling points.

Water is used for domestic consumption, irrigated agriculture, industrial production, recreation and tourism, fisheries production and sustenance of biodiversity. Lake Malawi is pivotal to national 
socio-economic development. Agriculture remains the major water use, followed by domestic use, municipal water supply and industry. Water resource distribution is highly variable, both seasonally and geographically. Around $90 \%$ of runoff in major rivers, flowing into Lake Malawi, occurs between December and June [28]. Major water management challenges stem from population growth at c. 3\% and developmental pressures. Most rural communities are involved in intensive small holder farming, with attendant deforestation that poses a significant risk of increased runoff, reduction in groundwater recharge, and accelerated erosion, resulting in sedimentation of surface water bodies and a reduction in water-supply reservoir capacities. IWRM policy instruments are vitally required to sustainably manage water resources and maintain water supplies to both rural and urban communities alike, with existing plans to boost water supply (e.g., increased Kamuzu dam I capacity and Salima District supply pipeline from Lake Malawi), alongside irrigation (Bwanje) and hydro-power generation schemes.

\subsubsection{Hydrological-Hydrogeological Setting}

The study area sub-divides into four contrasting physiographic zones: the highlands, including the Dzalanyama Range, Dowa Hills and Dedza Mountain reaching elevations up to 2400 masl; the plateau area dominated by the Kasungu-Lilongwe Plain, a vast area of $6000 \mathrm{~km}^{2}$ varying between 1000 and 1800 masl; the Rift Valley escarpment, varying in altitude between 600-800 masl; and the Rift Valley lakeshore plains. Surface water drainage across these zones is illustrated in Figure 2a. Flows in many rivers draining into Lake Malawi, including the Lilongwe, Diamphwe and Linthipe, are influenced by remote upland plateau occurrence of extensive 'dambo' grass-covered swampy valley(s) in the Chichewa language [29] (some illustrative areas of dambo occurrence are shown in Figure 2a).

Details of the geological setting detail are found within three articles covering various parts of the study area [29-31]. The area is mostly underlain by Precambrian 'Basement' Complex rocks comprising gneisses, schists and metamorphosed igneous intrusions. The Precambrian basement intrusives, typical of granular felsic intrusive igneous rock formation (Granite), occurs in the south west Dzalanyama Range. The coarse-grained intrusive igneous rocks (Syenite) occur within the Kasungu-Lilongwe Plain and parts of the Dedza District. The Quaternary alluvium, colluvium and lacustrine deposits occur along lakeshore areas of Lake Malawi within the Rift Valley plain. Most of the alluvial deposits arise from the erosion of rock material from the Rift Valley escarpment slopes [31,32]. The catchment area is characterized by Basement Complex aquifers, fracture zones in the escarpment zone, and alluvial aquifers (Figure $2 b$ ) in the rift valley floor. Basement aquifers occur in weathered or fractured zones of Cambrian Basement Complex rocks with generally low yielding boreholes, up to $2 \mathrm{~L} / \mathrm{s}$, that dominate the western and central areas. In the east, alluvial aquifers predominantly occur as Quaternary alluvial deposits and may be high yielding, up to around $20 \mathrm{~L} / \mathrm{s}$ [33]. They predominantly comprise mixed clays, silts, sands and gravels. Borehole yields in the escarpment zone may be as high as $12 \mathrm{~L} / \mathrm{s}$ [32,34]. Details of the above are considered further in our system conceptualization. 



Figure 2. Study area: (a) Topography and key physiography; (b) Aquifer types.

\subsubsection{Climate}

The Lake Malawi Basin experiences a tropical-continental climate with two distinct seasons: a wet season from November to April, and a dry season from May to October [35]. The dry season is characterized by south-easterly trade winds (the Mwera) and the wet season by weaker north-easterly winds (the Mpoto). The Inter Tropical Convergence Zone (ITCZ), the Zaire Air Boundary (ZAB), and tropical cyclones are the three large-scale (synoptic) systems that bring rainfall to the basin [35]. According to the revised Köppen-Geiger system, which is based on a large global dataset of long-term monthly precipitation and temperature station time series, Malawi's climate may be classified as Aw 
or Savannah. The defining criteria for this type of climate is Not (Af) \& Pdry $<100-\mathrm{MAP} / 25$, where Af is rainforest, MAP is mean annual precipitation, and Pdry is precipitation of the driest month [36]. Based on 2000-2018 precipitation data gathered from Malawi's Department of Climate Change and Meteorological Services (DCCMS), annual rainfall in the catchment area exhibits a mean of $956 \mathrm{~mm}$ and a range of $482-2128 \mathrm{~mm}$.

Temperatures are also influenced by the diverse topography, typically decreasing with increasing altitude. Mean maximum and minimum temperatures are 30.3 and $10.3{ }^{\circ} \mathrm{C}$, respectively. Maxima occur in October/November and minima in June/July. Malawi is vulnerable to climate change influence, arguably already occurring on the basis of increased drought and flood event frequencies [24,25].

\subsection{Water Sampling and Analysis}

Water sampling was undertaken as three sets of isotopes and hydrochemical surveys aimed at capturing seasonal variability. A total of 221 samples were collected from 69 sampling points between March 2014 and June 2018, with a breakdown of sample type provided in Table 1. The first survey was conducted from March 2014 to August 2015 (82 samples), the second from June to December 2017 (43 samples) and the third from June to August 2018 (96 samples). Each covered a wide range of water types, aiming to provide representative catchment coverage. The precipitation samples from the MNIP were collected using dip-in samplers designed to prevent evaporation (and eliminate the need for paraffin oil) [37]. Our local precipitation data was augmented by precipitation isotopic data from the surrounding Global Network of Isotope in Precipitation (GNIP) stations in Mozambique at Gorongosa (eight samples) and Chitengo (four samples) and Zambia at Ndola (154 samples) to better characterize local meteoric conditions [38]. Our Local Meteoric Water Line (LMWL) was calculated based on errors-in-variables (EIV) regression [39] and is referred to as EIV-LMWL. Groundwater samples were collected from community supply boreholes fitted with (Afridev) hand pumps that were in regular use for supply and hence well purged. Lake Malawi isotope samples were collected remote from estuaries $1 \mathrm{~km}$ from the shoreline via boat and bespoke depth sampler.

Table 1. Summary of isotopic and hydrochemical sampling undertaken (2014-2018).

\begin{tabular}{cccc}
\hline Source Type & No. of Sampling Points & No. of Isotope Samples & No. of Hydrochemical Samples \\
\hline Surface water & 22 & 50 & 23 \\
Groundwater & 43 & 73 & 38 \\
Precipitation & 4 & 37 & - \\
Total & 69 & 160 & 61 \\
\hline
\end{tabular}

Water samples for stable isotope analysis were collected using dedicated amber bottles for analysis of deuterium and oxygen-18 ratios using an automated Picarro Isotopic Water Analyser (IWA) at the MoAIWD IHL, incorporating a water laser spectroscopy-based approach. Samples were stored at $4{ }^{\circ} \mathrm{C}$ and away from sunlight during transportation and holding at the laboratory. Analysis involved daily calibration of heavy and light standards encompassing the anticipated range of isotopic composition in samples, alongside use of a daily control mid-range standard intermediate between heavy and light standards. The IWA was prepared by running two vials of deionised water and the quality of measurement was checked by inspecting concentration peaks with an acceptable range of $19,000-21,000 \mathrm{ppm}$. The precision $(2 \sigma)$ of isotope analysis was $\pm 0.2 \mathrm{ppm}$ for Oxygen-18 and $\pm 2.0 \mathrm{ppm}$ for Deuterium. The isotopic analysis was conducted in line with International Standard Procedures [40] and quantification and validation of results was accomplished via dedicated LIMS software.

Electrical Conductivity (EC), Total Dissolved Solids (TDS) and $\mathrm{pH}$ were measured on site using a portable multi-meter (Model: HI-98194) for a representative subset of samples (61) also subjected to hydrochemical analysis. Hydrochemical samples were collected in a distilled water rinsed pair of acidified and non-acidified polyethylene bottles. Samples were stored at $4{ }^{\circ} \mathrm{C}$ during transportation and at the MoAIWD Laboratory, and analyzed there for major ions, iron and fluoride. The samples 
were filtered through $0.45 \mu \mathrm{m}$ Whatman filters prior to laboratory analysis. The anions $\left(\mathrm{F}^{-}, \mathrm{Cl}^{-}\right.$, $\left.\mathrm{NO}_{3}{ }^{-}, \mathrm{SO}_{4}{ }^{2-}\right)$ and cations $\left(\mathrm{Fe}^{2+}, \mathrm{Na}^{+}, \mathrm{K}^{+}, \mathrm{Mg}^{2+}, \mathrm{Ca}^{2+}\right)$ were measured using ion chromatography (Ion Analyzer-Model: IA-300) Carbonate and bicarbonate concentrations were measured using titrimetric methods with hydrochloric acid. All field sampling and measurements, and laboratory analyses, were conducted in line with International Standard Procedures [41], and accuracy of analysis results was validated by calculating ion-balance, with adherence to an acceptable error of $5 \%$. The detailed list of surface water, groundwater and precipitation (within study area) stations is presented in Supplementary Materials (SM) - Tables SM2a, SM2b and SM2c, respectively.

\subsection{Baseflow Index Estimation}

To support system conceptualization, baseflow index (BFI) estimation was undertaken. Baseflow represents the proportion of river flow derived from groundwater from aquifers and other stored sources. Other stored sources may include slow-moving interflow (as opposed to rapid interflow), connected lake or wetland systems, and temporary storage in the banks of the river channel. Although it is generally accepted that baseflow is mainly derived from groundwater, it is important to acknowledge, in the absence of detailed site investigations, that these other sources may also contribute, depending on the catchment characteristics, although typically to a lesser extent [42]. Baseflow is commonly expressed as the BFI, defined as the ratio of baseflow volume to the total river flow volume. For the current scope (non-exhaustive), we simply draw upon BFI mean data from our parallel CJF programme activity to quantify BFI trends across Malawi using hydrometric (river discharge) data obtained from the Surface Water Division of the Department of Water Resources in the MoAIWD.

The river data archive spans from 1953 to 2010, but with data recording gaps, and differences in monitoring periods between gauges. BFI estimates were hence made of annual (1 November to 31 October), wet season (1 November to 30 April) and dry season (1 May to 31 October) arithmetic means (averages) for the entirety of the data available for each gauge. This approach provided good spatial coverage of the study area, encompassing nine rivers, but there is still a need to examine specific time-period data in future work.

Baseflow separation was used to analyze the river data and determine BFI for 14 river gauging stations over the time periods indicated: Nadzipokwe River 3E1 (1953-2010) and 3E2 (1957-2003), Namikokwe River 3E2 (1957-2003) and 3E5 (1957-2010), Livulezi River 3E3 (1956-2008), Nadzipulu River 3F3 (1957-2004), Linthipe River 4B1 (1953-2009), 4B3 (1957-2008) and 4B9 (1974-2010), Diamphwe River 4B4 (1957-2010), Lilongwe River 4C2 (1957-2010), 4D4 (1953-2009) and 4D24 (1991-2005), Nanjiri River 4C11 (1985-2010) and Lingadzi River 4E2 (1959-2005). Due to the sporadic nature of the river data, this study followed the approach set out in a recent study by Kelly et al. (2019) [28] which specifically demonstrated how to work with sporadic river data to quantify temporal variations in BFI. The approach utilized the BFI programme, an MS Excel ${ }^{\circledR}$ based tool developed by the Department of Geosciences in the University of Oslo [43]. The programme performs baseflow separation on daily river flow and separates the river flow into its 'surface runoff' component and its 'baseflow' component, which, in turn, allows for determination of the BFI. The BFI was calculated as the ratio of the baseflow volume to the total flow volume using the smoothed minima technique developed by the Institute of Hydrology (1980) [44], as described in Kelly et al. (2019) [28].

\section{Results}

\subsection{Baseflow Index Results}

Spatial distribution of BFI estimates confirms that baseflow is an important contributor to all river flows (Figure 3). Dry season baseflows are typically much higher than wet season baseflows, which are more comparable to the annual average. Overall, averages and standard deviations of the presented BFI data are: annual $0.52+0.14(27 \%)$, wet season $0.47+0.13(28 \%)$ and dry season $0.86+0.067$ $(8 \%)$. The marked increase, and decreased variation, in the dry season BFI is ascribed to the greatly 
reduced run-off. Towards the mid to late dry season there is little, if any, precipitation, with river flows becoming low (to very low) and tending to a BFI of unity-flows becoming totally dependent on groundwater baseflow. Where groundwater levels fall below riverbed, rivers may become influent and possibly cease to flow downstream. We do not examine low-flow data specifically, however, Sefe (1988) [45], who examined low-flow or no-flow conditions in the Linthipe catchment indicates of the five gauges considered in our study (covering central and northern areas), found that only the Linthipe 4B1 gauge regularly exhibited a no-flow condition.

Most annual and wet season BFI estimates, at around 0.5-0.6, indicate a consistent baseflow contribution to river flows. Gradual release from water storage sources such as dambo can account for the elevated BFI in upper reaches of the plateau. Low BFI values for the annual and wet season are prominent in two gauges close to Lilongwe City, and reasonably ascribed to increased runoff from urbanization there and the intensification of agriculture in surrounding areas. BFI trends observed along specific rivers demonstrate that Lilongwe baseflows decline downstream in the annual and wet season, but increase during the dry season (Figure 3). The river likely has influent reaches across the Lilongwe Plain. The Linthipe River baseflow declines between the plateau and just downstream of the escarpment, but a subsequent significant increase occurs towards the center of the Salima lakeshore plain (Figure 3). These data suggest river losses to ground water at entry to the lakeshore plain, followed by a baseflow increase upon approaching the Lake Malawi foreshore.



Figure 3. Average annual, wet-season and dry-season baseflow index (BFI) estimates from river flow gauging station records (all graphs are scaled per legend).

\subsection{Hydrochemical Results}

The descriptive summary for the hydrochemical analysis results of surface water and groundwater is presented in the Supplementary Material (SM)_Tables SM1a and SM1b, respectively, while full data sets for the hydrochemical analysis results of groundwater and surface water are presented in the Supplementary Material (SM) - Tables SM3a and SM3b, respectively. Surface waters are slightly alkaline (pH: 7.0-8.3) and fresh, with water hardness varying from very soft to hard (Figure 4a). TDS is generally low, ranging from 42 to $349 \mathrm{mg} / \mathrm{L}$, with a mean of $145 \mathrm{mg} / \mathrm{L}$. Dominant anions are bicarbonate 
and chloride, and cations, calcium and sodium. Groundwater summary data reveal similar ions dominate, but at higher concentrations (Figure $4 \mathrm{~b}$ ). The $\mathrm{pH}$ range was fair, from 5.3 to 8.3 and of mean 6.91. Most groundwater points were slightly acidic, with TDS varying from low to moderate at 132-1474 mg/L, and of mean $541 \mathrm{mg} / \mathrm{L}$ and median $505 \mathrm{mg} / \mathrm{L}$. These compare favorably with WHO guidance, with drinking water being recognized to be of good palatability at $<600 \mathrm{mg} / \mathrm{L}$ TDS, but becoming increasingly unpalatable (and brackish) at $>1000 \mathrm{mg} / \mathrm{L}$ TDS.

Groundwater may be classified into four main groups based on the Piper plot, with dominant occurrence of the Ca-Mg-HCO3 water type (Figure 5a). Cation exchange processes are evidenced by a mixing line in the cation ternary with the addition of sodium into the groundwater replacing calcium. The Durov plot (Figure 5b) supports the dissolution of evaporite minerals, simple mixing, and ion exchange as the possible controls. The majority of groundwater samples are in Fields 1 and 2, characteristic of fresh recharging waters rich in $\mathrm{Ca}-\mathrm{HCO} 3$, followed by Field 5, groundwater exhibiting simple mixing or dissolution processes. The remaining populated fields contain few samples, inferring less important controls. These include Field 8, with three samples evidencing groundwater associated with reverse ion exchange of $\mathrm{Na}-\mathrm{Cl}$ water type, and just a single sample in both Field 3 groundwater-rich in $\mathrm{Na}-\mathrm{HCO} 3$, resulting from the ion exchange process, and Field 9-end-point waters with dominant occurrence of $\mathrm{Na}-\mathrm{Cl}$ water.
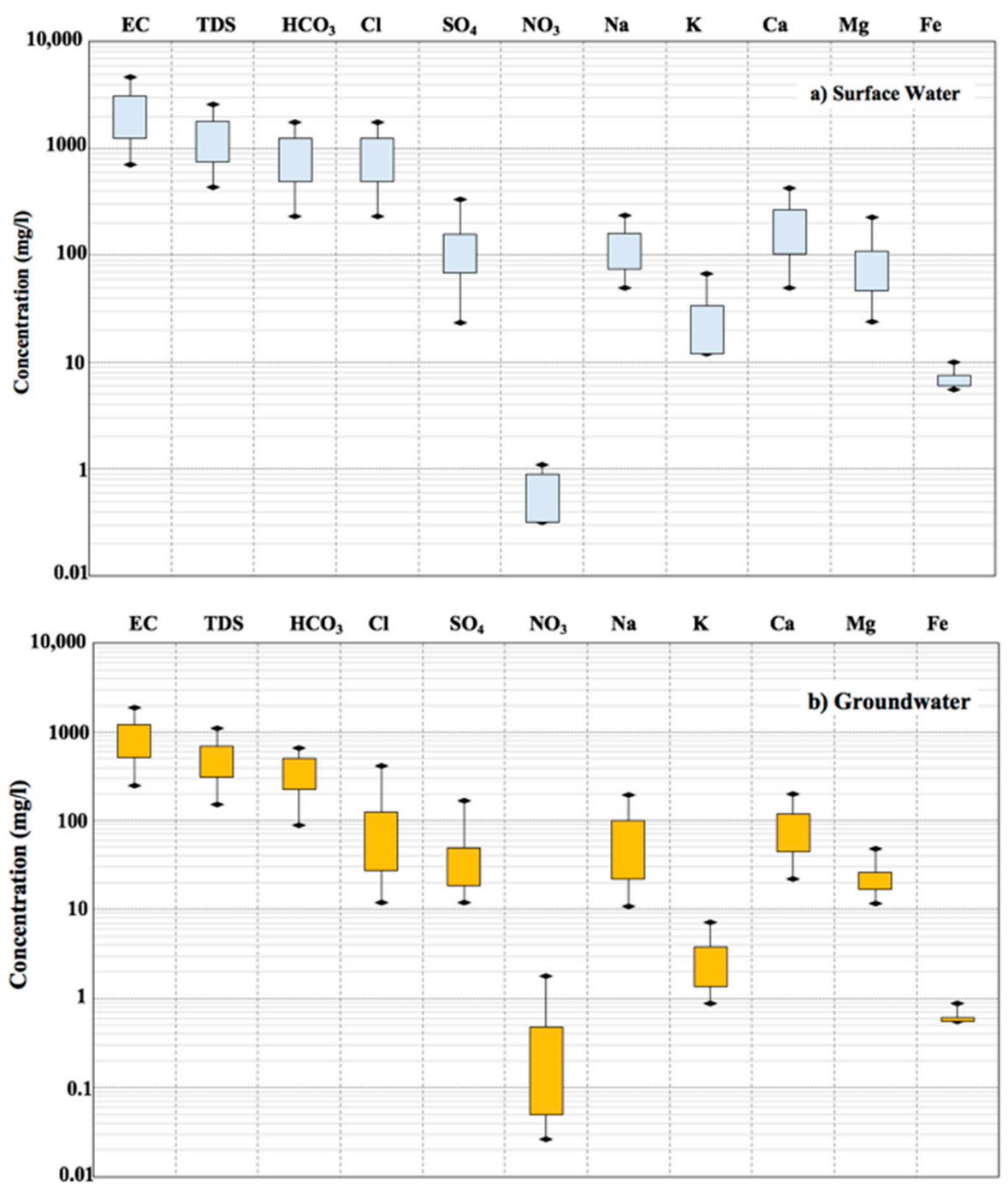

Figure 4. Observed electrical conductivity (EC), total dissolved solids (TDS) and major ions in: (a) Surface water; (b) Groundwater. 
a)

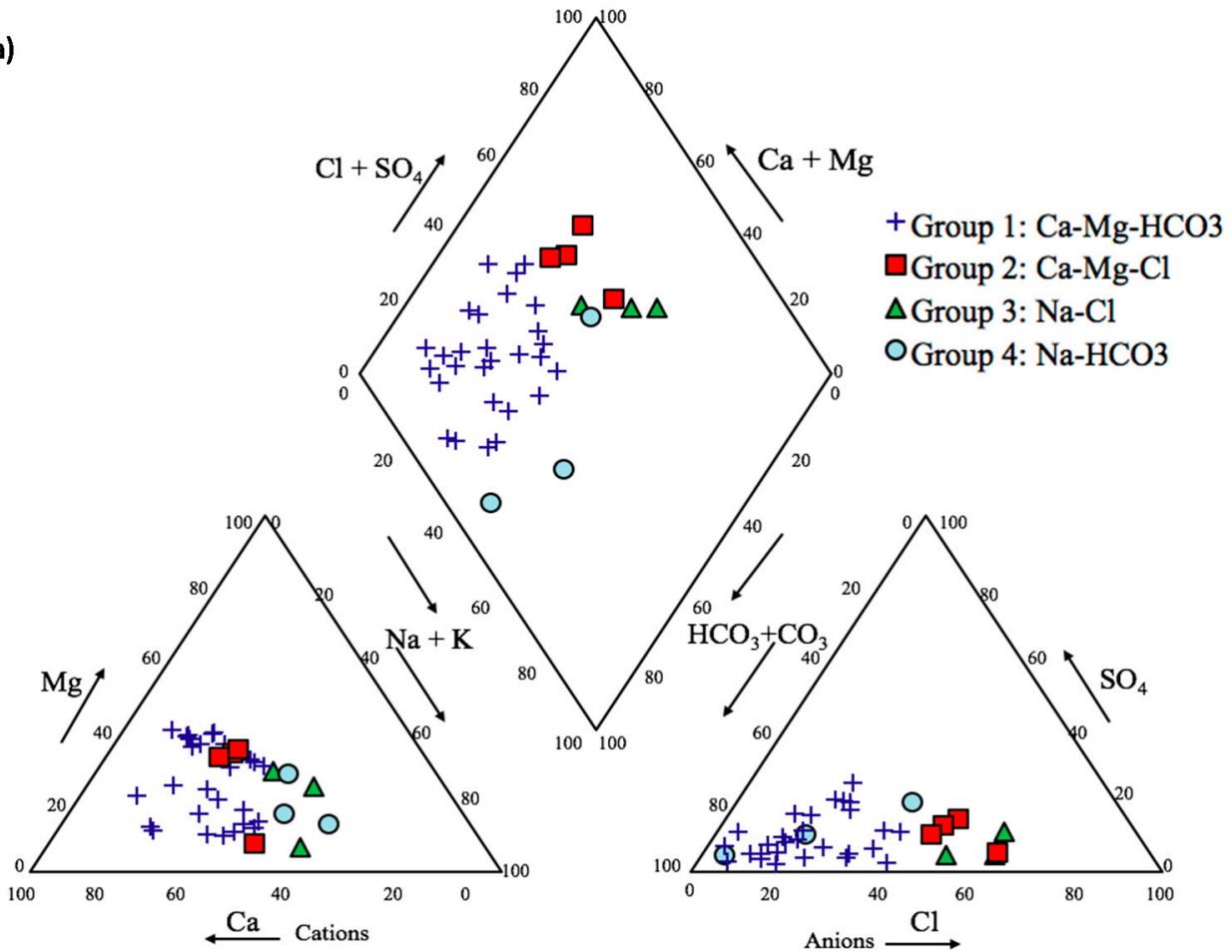

b)

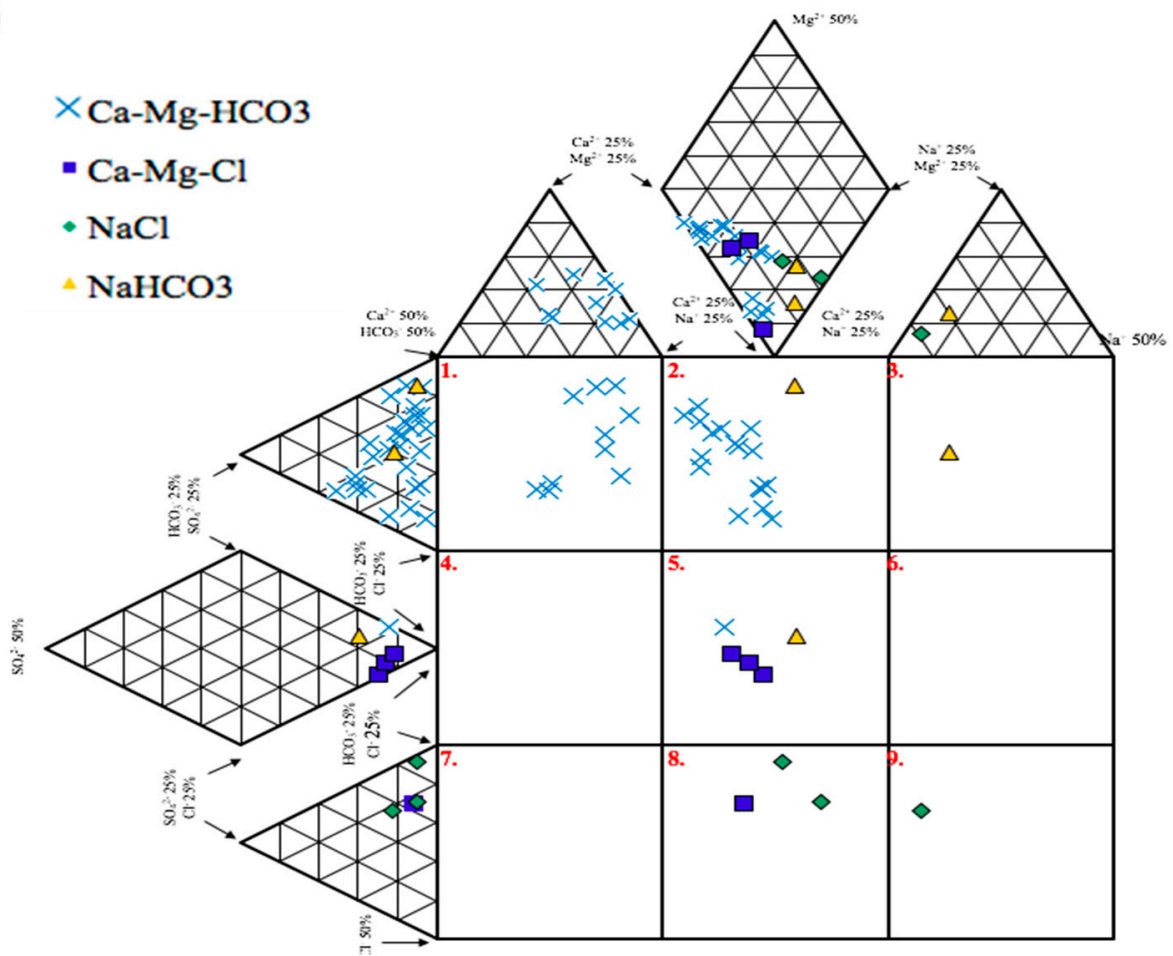

Figure 5. Observed groundwater data: (a) Piper trilinear plot; (b) Expanded Durov diagram (using hydroCHEM 2.0 software).

All upland, highland-plateau area sites are predominantly Ca-Mg-HCO3 water type (Figure 6) and accord with the quality expected of fresh recharging waters. All sites are near river systems and, hence, where discharge occurs, baseflow is probably of this water type. The predominant $\mathrm{Ca}-\mathrm{Mg}-\mathrm{HCO} 3$ water type remains evident in the lowlands, low escarpment to lakeshore plain area at 12 sites, however, hydrochemistry displayed is heterogeneous. The remaining eight sites contain other water types 
enriched in calcium or sodium, four of the sites being those closest to the Lake Malawi shoreline. The reverse is shown for the most northern assemblage of lakeshore plain sites (just south of the Lilongwe River in Salima) that exhibit enriched calcium or sodium water types towards the inland side rather than the shoreline. This observation may be ascribed to river infiltration and/or increased precipitation (compared to the upland plateau).



Figure 6. Groundwater types observed spatially in the study area.

Heterogeneity of water types in the flood plain implies a combination of processes, including river infiltration contributing lower TDS water to aquifers; enriched calcium or sodium in samples, indicative of older groundwater of a longer flowpath and increased mineral solution and/or the influence of lowland (phreatic) evaporation influences or wet-season infiltration of Lake Malawi water. Certainly, the lowland groundwater hydrochemical heterogeneity is indicative of more complex, multi-process controls compared to the homogeneity and inferred process uniformity in the probable recent recharge-dominated upland groundwater.

\subsection{Stable Isotope Results}

\subsubsection{Precipitation}

Precipitation $\delta^{2} \mathrm{H}$ values $(\mathrm{n}=203)$ ranged from $-121.2 \%$ o to $24.2 \%$, with a mean of $-29.8 \%$, and $\delta^{18} \mathrm{O}$ ranged from $-17.5 \%$ o to $3.0 \%$, with a mean of $-5.2 \%$ o (Table S1 in Supplementary Materials). Linear (EIV) regression defined the Local Meteoric Water Line (LMWL) as: $\delta^{2} \mathrm{H}=7.7(0.09) \delta^{18} \mathrm{O}+10$ (0.55), $\mathrm{R}^{2}=0.99$ (Figure 7), which compares with the Global Meteoric Water Line (GMWL) defined by Craig (1961) [46] as $\delta^{2} \mathrm{H}=8 \delta^{18} \mathrm{O}+10$. The local precipitation isotopic data has a mean intercept of $14.3 \%$, exhibiting excess deuterium ascribed to local vapor recycling, slightly above the GMWL intercept of $10 \%$. The wide variation evident in isotopic composition (range: 88.4 for $\delta^{2} \mathrm{H}, 10.6$ for $\delta^{18} \mathrm{O}$ ) (and found in our wider Malawi studies) is ascribed to the aforementioned different rain-bearing 
systems-influenced local precipitation, alongside the influence of geographic controls upon local rainfall variation.

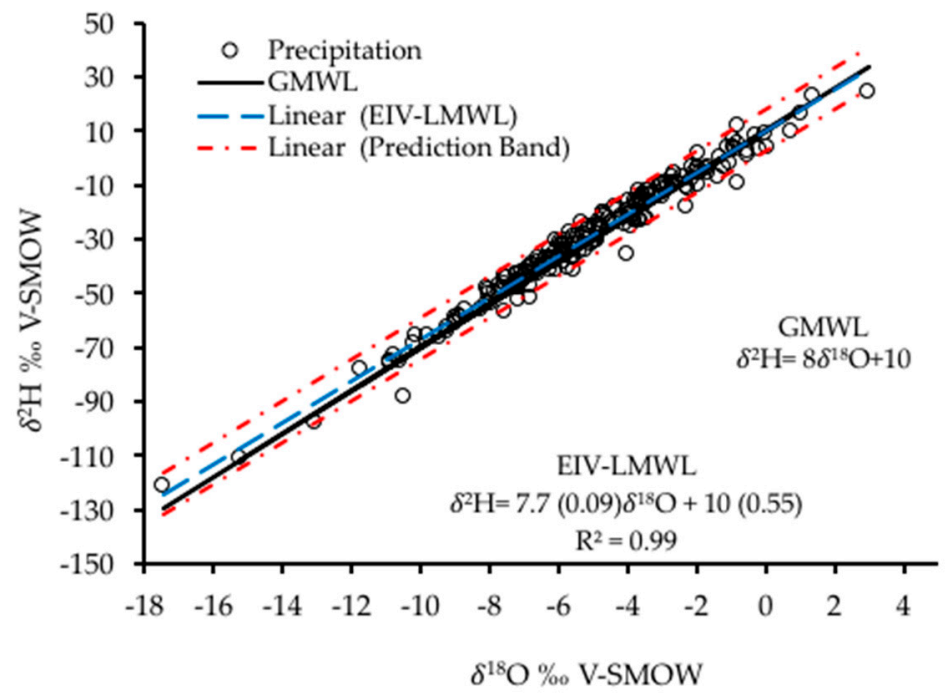

Figure 7. Plot of $\delta^{2} \mathrm{H}$ and $\delta^{18} \mathrm{O}$ for precipitation isotopic samples. LMWL represents the Local Meteoric Water Line for the Linthipe River and South West Lake Malawi Catchments calculated based on errors in variables (EIV).

\subsubsection{Groundwater}

Groundwater $\delta^{2} \mathrm{H}(\mathrm{n}=73$ samples (from $\mathrm{n}=43$ points)) ranged from $-43.9 \%$ o to $-23.3 \%$ o of mean $-37.6 \%$, and $\delta^{18} \mathrm{O}$ from between $-6.7 \%$ o and $-4.2 \%$ of mean $-5.9 \%$ o (Table S2 in Supplementary Materials). Deuterium excess ranged from $0.94 \%$ o to $13.0 \%$ of mean $9.6 \%$. Most groundwater samples plot within the prediction interval and along the meteoric water lines (Figure 8a) providing strong evidence of non-evaporated local precipitation recharge input to groundwater in those samples, arbitrarily assigned as 'Group G1' in Figure 8a. Some groundwater samples, though, assigned as 'Group G2', deviate from the meteoric water lines and follow a local evaporation line (LEL) defined by $\delta^{2} \mathrm{H}=5.3 \delta^{18} \mathrm{O}-6.2$. Such deviation is ascribed to excess $\delta^{18} \mathrm{O}$ arising from secondary evaporative enrichment and accounted for by groundwater subjected to evaporative fractionation, either during the runoff that preceded infiltration, or occurring within the groundwater body itself (probably from shallow groundwater phreatic evaporation), or possibly groundwater-containing infiltrated Lake Malawi water previously subject to evaporative enrichment. Data segregation to lowland versus upland groundwater (Figure 8b) confirms that the more enriched (although not all) of the Group G1 data correspond to 'lowland' groundwater points in the lakeshore districts of Salima and Dedza.

In sum, groundwater isotopic compositions largely follow the LMWL with modest variation (range: $21 \%$ o $\delta^{2} \mathrm{H}, 2.5 \%$ o $\delta^{18} \mathrm{O}$ ) suggesting a simple areal groundwater recharge, largely by local precipitation. Some isotopic shift below the LMWL, however, suggests significant evaporative enrichment of groundwater near Lake Malawi during the dry season (see later). The full datasets for the stable isotopes analysis results of groundwater are presented in the Supplementary Material (SM)-Table SM4a. 

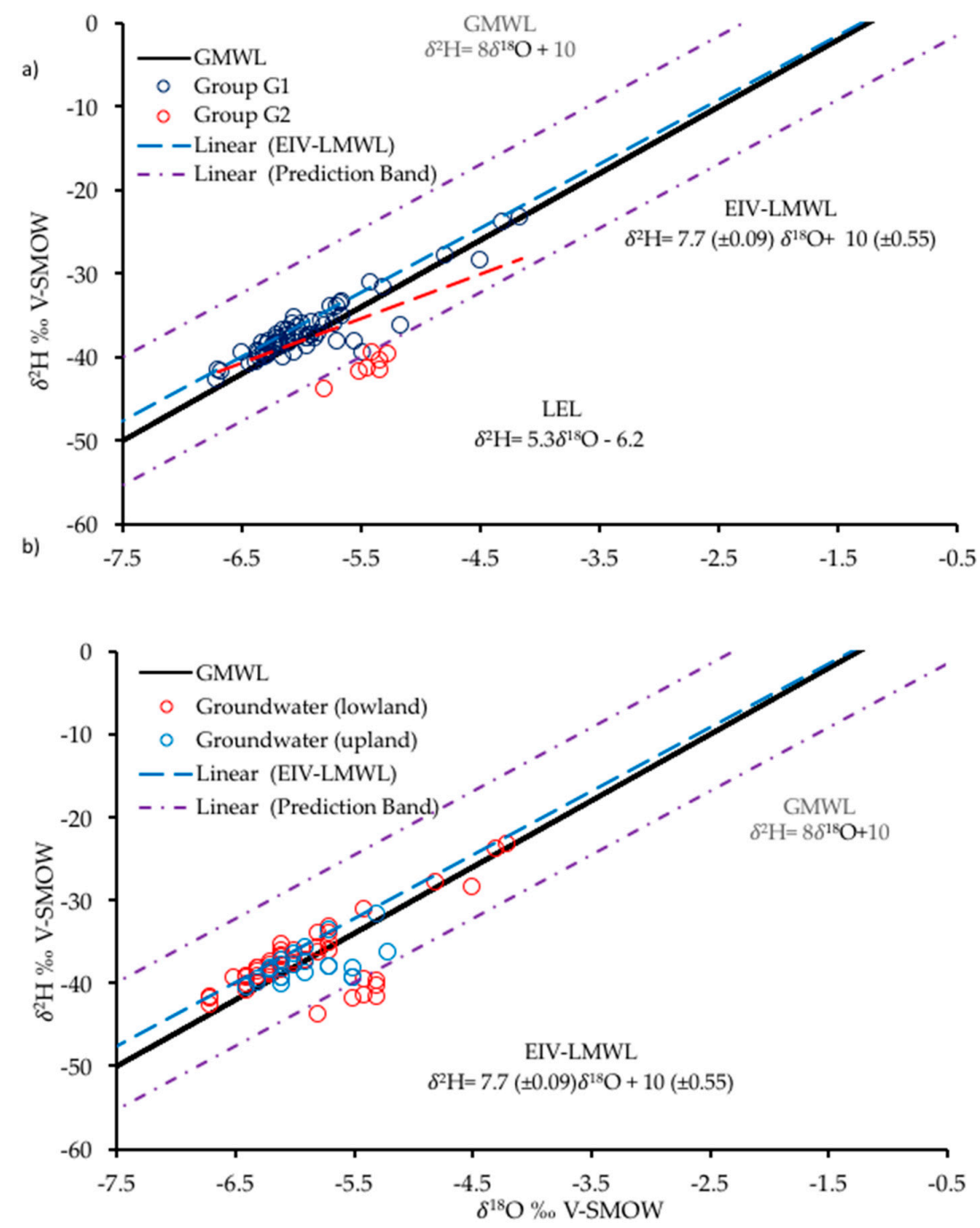

Figure 8. (a) Plot of $\delta^{2} \mathrm{H}$ and $\delta^{18} \mathrm{O}$ for groundwater samples; (b) Shown (zoomed in) with data segregated to upland and lowland sample sites.

\subsubsection{Surface Water}

Fifty surface-water isotope samples from 22 points (16 rivers, three reservoir (Kamuzu) dams, three from Lake Malawi) yielded wide-ranging $\delta^{2} \mathrm{H}$ compositions from $-44.3 \%$ o to $-20.1 \%$ of mean $-15.3 \%$, and for $\delta^{18} \mathrm{O}$, between $-6.8 \%$ ond $3.0 \%$ of mean $-2.5 \%$ o (Table S3 in Supplementary Materials). Most samples plot outside the prediction interval and below the meteoric water lines, along a Local Evaporation Line (LEL) defined by $\delta^{2} \mathrm{H}=6.3 \delta^{18} \mathrm{O}+0.57$, comprising Lake Malawi (we note that additionally including lake data from the Gonfiantini et al. (1979) study [47] would have resulted in only a minor shift in our LEL intercept, from 0.57 to 0.54 ), the Kamuzu dam (dry season) and the river samples arbitrarily assigned to Group S2 (Figure 9a). Although, for the lower value data $\left(\delta^{2} \mathrm{H}<c\right.$. $-20 \%$ o, $\delta^{18} \mathrm{O}<c .-3.5 \%$ ), most do follow the meteoric water lines, comprising the Kamuzu dam (wet season) and river samples assigned to Group S1. Samples from Group S2, Lake Malawi, during all seasons, and the upland Kamuzu dam in the dry-season, all exhibited isotopic evidence of evaporative enrichment, with Lake Malawi samples forming the high-evaporation end member. Samples from Group S1, the vast majority of river samples, and the Kamuzu dam in the wet season exhibited isotopic signatures consistent with local precipitation that followed the LMWL and infers that runoff (and rapid interflow) accounted for most riverine flows. 


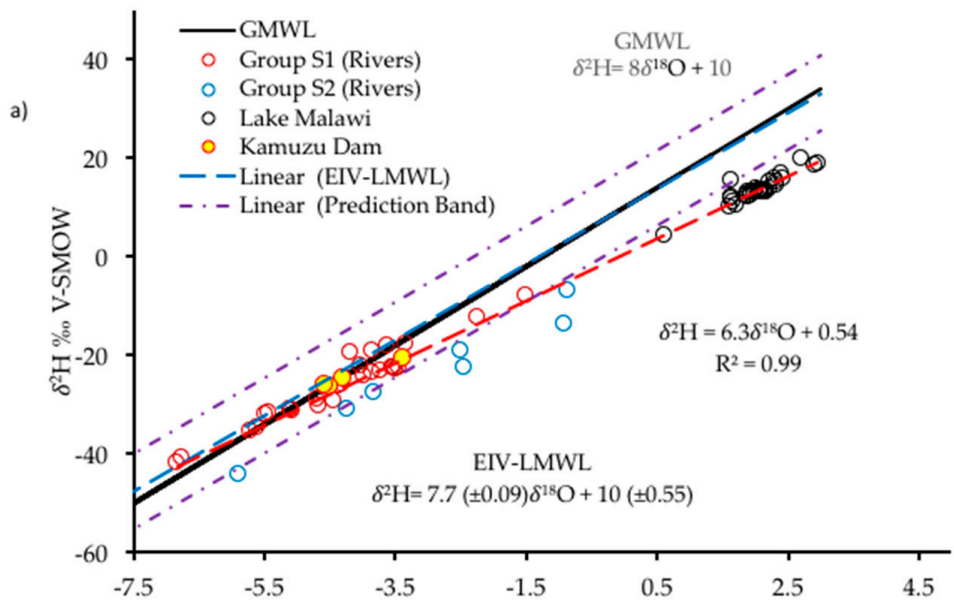

b)

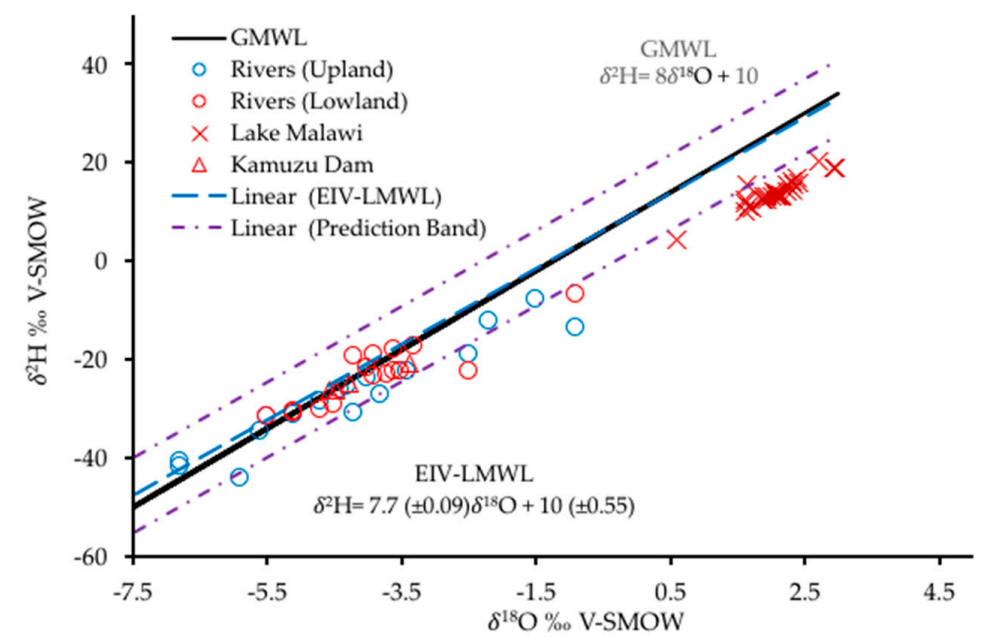

Figure 9. (a) Plot of $\delta^{2} \mathrm{H}$ and $\delta^{18} \mathrm{O}$ for surface water samples; (b) Shown with data segregated to upland and lowland sites.

Six river samples exhibited a degree of enrichment, intermediate between the bulk of river data and Lake Malawi samples. Segregating the data between upland and lowland sites reveals that the least evaporated signatures $\left(\delta^{2} \mathrm{H}<c .-30 \%, \delta^{18} \mathrm{O}<c .-4.0 \%\right.$ o $)$ are mainly upland sites and the more evaporated signatures (over the above range) are mainly lowland river sites (Figure $9 \mathrm{~b}$ ). For instance, of the six intermediate signature sites, four are upland. Although not conclusively shown, long residence times in dambo, vulnerable to evaporation influences may contribute to enhanced evaporative signatures in the upland river samples. Generally, though, the variation in surface water is consistent with that of precipitation, suggesting that recent local precipitation significantly contributes to river flows in the catchments.

In sum, isotopic compositions of surface water show a wide variation (range: $64 \%$ o $\delta^{2} \mathrm{H}$, $9.8 \%$ o $\delta^{18} \mathrm{O}$ ) consistent with local precipitation spatial variation, and support the view that local precipitation contributes largely to river flows, particularly during the wet season. The full datasets for the stable isotopes analysis results of surface water are presented in the Supplementary Material (SM)-Table SM4b.

\subsection{Groundwater-Hydrochemical and Isotopic Evidences Combined}

The dominant $\mathrm{Ca}-\mathrm{Mg}-\mathrm{HCO} 3$ groundwater type is plotted along the LMWL length, thus supporting the young water occurrence from non-evaporated local precipitation recharge (Figure 10a). Relationships, however, are not clear. This water type also occurs as outliers removed from the LMWL. 
Likewise, the other water types also occur both along the LMWL and as outliers. The latter is expected, as those water types may arise, in part, from evaporative processes. Examining the TDS of these samples is not conclusive either (Figure 10b). Whilst some outliers do correspond with the higher TDS anticipated from evaporation, higher TDS points also occur on the LMWL. TDS also varies across both the data outliers and data plotting along the LMWL. Whilst not easy to interpret, collectively the data suggest a heterogeneous mix of influential processes relating to groundwater sample flow-path history and/or evaporative influences. Notably though, the greatest complexity of the processes suggested by the variation in hydrochemical type and isotope signatures is most apparent near the lakeshore area, where much of the outlier data tend to occur. This signature complexity is consistent with the process complexity anticipated in the lakeshore plains near Lake Malawi, towards the termination and possible convergence of different groundwater flow paths and water histories.

a)

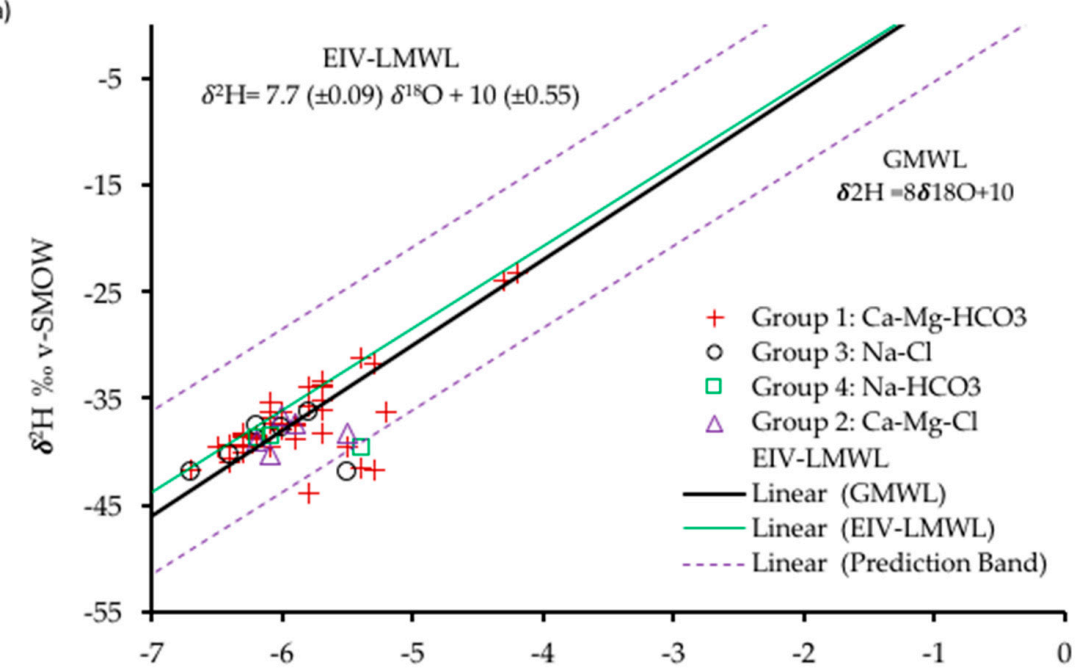

b)

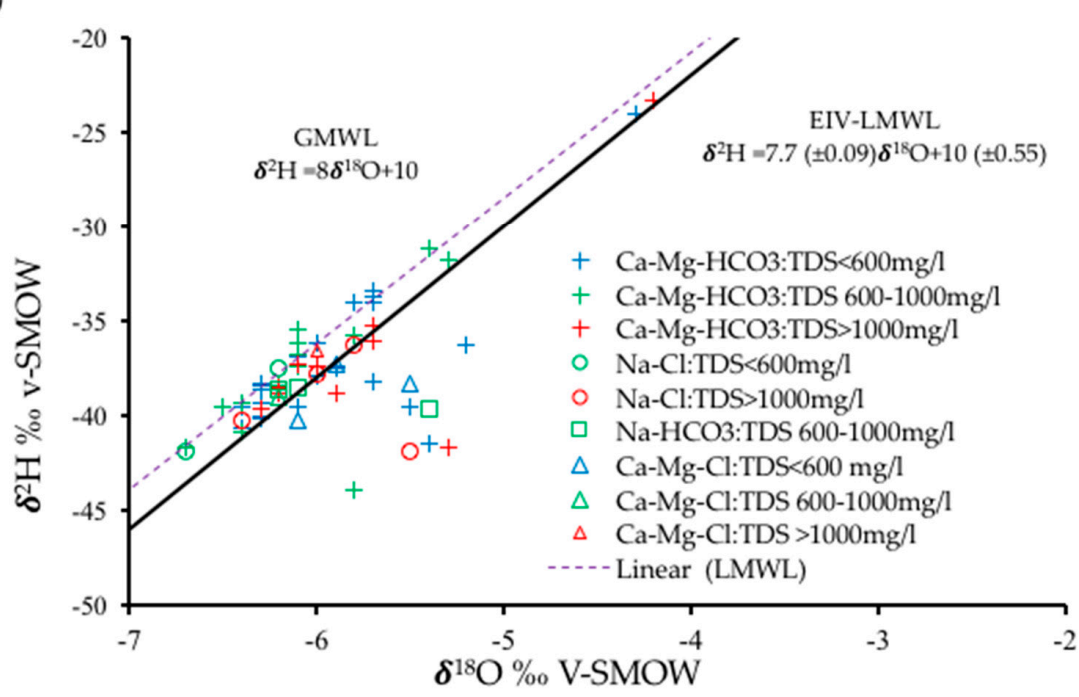

Figure 10. (a) Isotopic composition of groundwater types; (b) Isotopic composition of TDS-classified (blue lowest, red highest) groundwater types.

\subsection{Dynamics: Seasonal Effects and Groundwater-Surface-Water Interactions}

Seasonal variability in surface-water isotopic composition is observed, with samples plotting along the meteoric water lines during the wet season, but with a pronounced tendency to plot below lines during the dry season (Figure 11a). This supports the theory of isotopic enrichment due to increased evaporative effects occurring during the dry season. Lowland and upland river samples 
both show dry season enrichment. These results are consistent with the probable influence of dambo, sustaining dry season flows and their extensive surface area, combined with prolonged water residence times causing them to be vulnerable to evaporation processes.

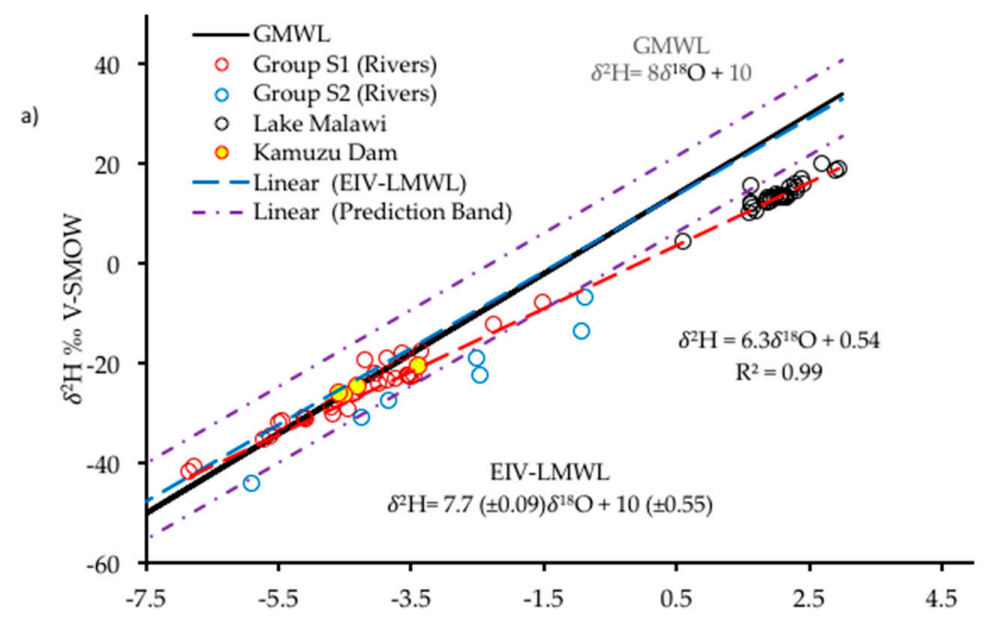

b)

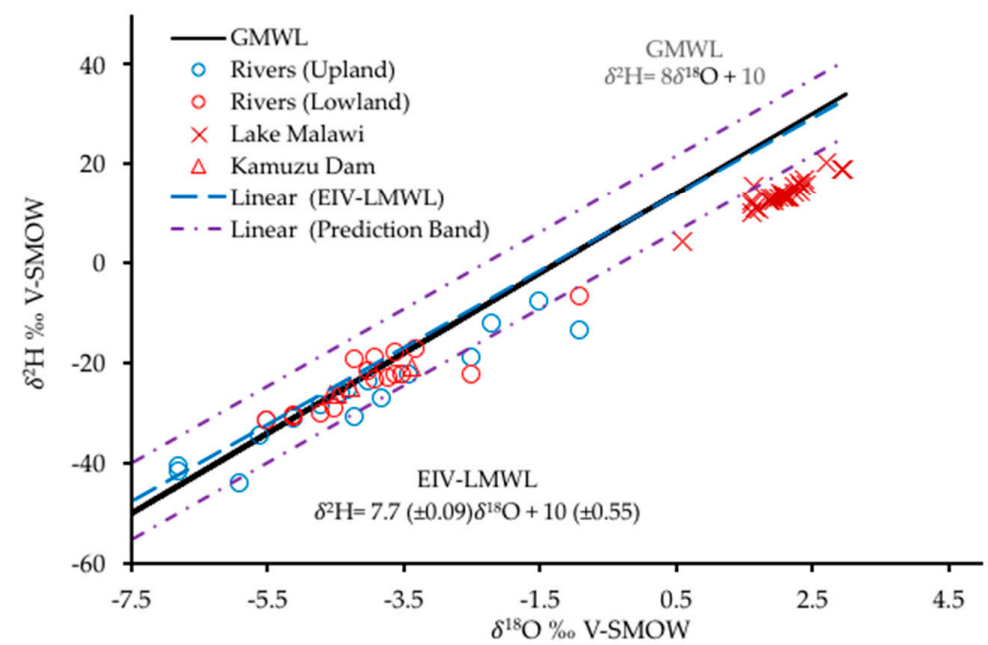

Figure 11. Seasonal variation in isotopic composition observed in: (a) Surface water, (b) Groundwater samples (dry season—red symbols; wet season—blue symbols).

Groundwater isotopic composition also varies between the dry and wet season (Figure 11b). Points cluster along the meteoric water lines during the wet season with minimal departure during the dry season, although samples both plot along and deviate from meteoric lines. Such seasonal responses in groundwater, regarded as slow moving and often unable to dynamically respond, suggest that parts of the groundwater system are moderately dynamic. The fact that the majority of samples do plot along the meteoric water lines suggests most groundwater samples comprise relatively recent, local recharge precipitation inputs. This is consistent, with most wells sampled generally being shallow, $30-50 \mathrm{~m}$ depth, and screened perhaps $0-20 \mathrm{~m}$ below water table. Observations would also be consistent with the low storage of the (uplands) fractured and weathered bedrock aquifers, which would lead to a high turnover of water. The latter would also occur in the shallow alluvial aquifers, where these are transmissive and permeable (sand/gravel rich). These observations are consistent with the 'young' hydrochemical $\mathrm{Ca}-\mathrm{Mg}-\mathrm{HCO}_{3}$ water type widely encountered.

Groundwater points exhibiting enrichment of dry season samples (Figure 11b), displaying predominant occurrence in the lakeshore plains (Figure 8b), support the probable influence of evaporative processes on some areas of the lakeshore plain groundwater. The variation in hydrochemistry of these samples 
(Figure 10) does suggest that a mix of processes are responsible, including phreatic evaporation, infiltration of evaporated influent river waters and residual, infiltrated, earlier wet-season Lake Malawi water, yet to be flushed from the aquifer system.

Most groundwater isotope signatures occur within a quite restricted portion of the surface-water signatures (compare shaded boxes in Figure 11a,b), suggesting the groundwater sampled did not contain large quantities of infiltrated river, or Lake Malawi, surface water. This accords with a groundwater baseflow-dominated exchange with the surface water system. That said, boreholes would probably need to be very close to an infiltrating river reach, or temporarily infiltrate Lake Malawi, to predominantly extract influent waters undiluted by resident groundwater.

\subsection{System Conceptual Model}

A conceptualization of the water resource system is illustrated in Figure 12 and expanded upon below. The model is generated from our survey findings above and knowledge gained from our detailed review of the hydrogeological [33] and geological (memoir) literature pertaining to the study area [29-31] variously referred to below. Whilst dated, this late 1960s to early 1980s archive of research remains valuable due to its limited updates since. The linking of isotopic lines of evidence to processes is conveniently summarized within the Figure 12 'isotopic signatures' labels. The key 'flow processes' and 'hydrochemistry' controls are also labeled. Conceptualization of the various physiographic zones is briefly expanded upon below.

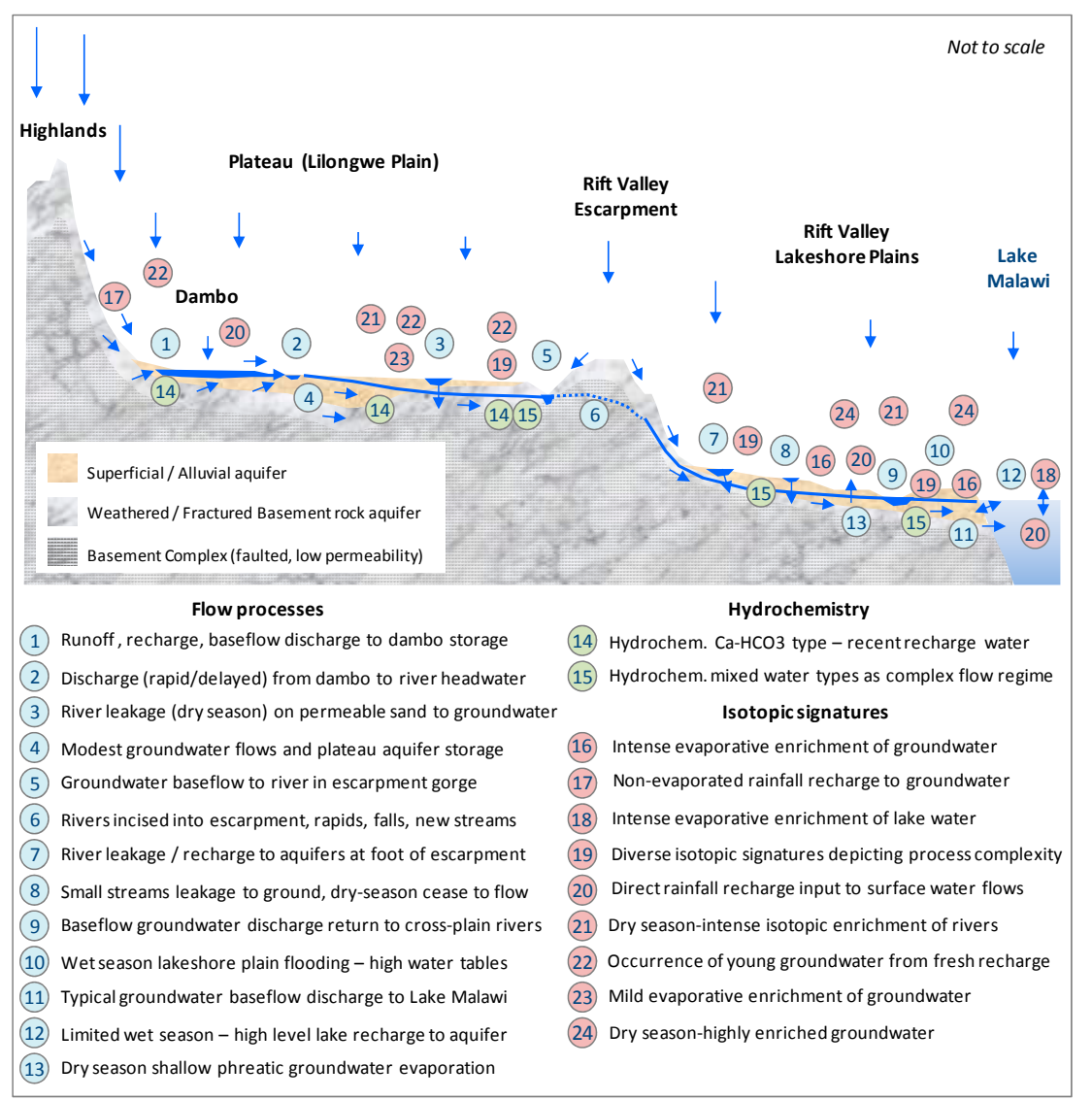

Figure 12. System conceptual model of water resource occurrence, process controls and isotopic signature features (acknowledging the contributions of flow understanding from Smith-Carington and Chilton, (1983) [33] (their Figure 3.18)). 


\subsection{Dambo}

A Dambo comprises a system of poorly defined water channels in waterlogged sediments. Predominantly fine-grained sediments accumulate in the centre, with more sandy, permeable deposits at the head and periphery [29]. Groundwater is near the ground surface, draining into the dambo from the surrounding fractured basement aquifer units with supporting, often perennial, baseflow to the dambo from adjoining weathered basement and colluvium [31,33]. Geological control occurs, dambo and water courses aligning with faulted or jointed areas of structural weakness that may serve as preferential conduits of groundwater flow [29,30]. Rainfall on saturated dambo results in steeply rising river hydrograph limbs, forming anomalously broad peaks. These arise from delayed discharge of impeded, tortuous flows through and around the dambo low-permeability sediments and grasses. Dambo hence provide temporary reservoir storage, buffering precipitation inputs and delaying groundwater baseflow expression. Although end-of-wet-season flows may ultimately decline steeply, accelerated by high evaporative losses from the dambo surface, often, slow groundwater underflow and subsequent baseflow contributions persist, allowing dambo to sustain river flows overall, or for much of the dry season [33]. Our observed enhanced evaporative isotopic signatures in some upland river samples support the above conceptualization.

\subsection{Plateau-Upland Area}

Water courses traversing the plateau appear subject to geological control. The long, straight stretch of the Lilongwe River on the South Lilongwe Plain near the Likuni Mission area may be ascribed to the strike of the gneisses or strike joints [30]. Such occurrences may facilitate the groundwater discharge to baseflow, although flows from the underlying weathered basement to the plateau reaches are probably not significant [33]. Superficial deposits may be thick, up to $40-50 \mathrm{~m}$ on the Lilongwe Plain, with the accumulated sandy riverbed alluvium common to many major rivers that could support baseflows $[29,30]$. On some reaches, groundwater levels may be (seasonally) below the base of the river, which then become influent and recharge underlying groundwater [33]. Upland area isotope signatures generally support a non-evaporated rainfall recharge to groundwater and direct rainfall input to surface flows and young groundwater from recent recharge. A greater spatial and temporal density of sampling would be required to confirm the seasonal and/or spatial groundwater-surface-water relationships postulated, together with further hydrograph-river gauging works. Hydrochemical contrasts between mostly young waters appear to be limited, and hence less diagnostic.

\subsection{Rift Valley Escarpment}

Approaching the rift valley up-warped escarpment edge, weathered basement-superficial deposits are typically thin and groundwater underflows through the eastern plateau area are potentially limited. Most groundwater likely drains towards increasingly incised, deep gorge, main river channels and contributes to the baseflow. Rivers dissect the escarpment that falls stepwise to the rift valley floor due to "en echelon" faulting where gorges and rapids occur [33]. Main rivers are joined by many smaller rivers (e.g., the Ngodzi) having their headwaters in the escarpment (Figure 2a, recognizing smaller rivers are not shown). Although baseflow may occur from the fractured basement rock to the rivers and underflow into the alluvial deposits, these are likely modest, as groundwater storage and transmissivities are generally low (although not easily quantified due to (faulted) system discontinuity) [33]. Our survey does not characterize this zone, but it is reasonably surmised that hydrochemical-isotope signature ranges may begin to increase as they manifest gathering process complexities.

\subsection{Lakeshore Plains}

Very gentle gradients across the rift valley lakeshore plains lead to significant deposition of river sediment loads, with channels becoming tortuous and the plains vulnerable to wet season flooding. Dambo may also occur on the lakeshore plain [31]. Most main rivers leave the escarpment on a level 
with the lakeshore plain, and may initially lose much of their flow into the alluvial sediments and weathered basement that is hydraulically contiguous close to their entry to the plains, especially where flowing over alluvial fan-permeable sediments that have debouched from the escarpment [33]. Streams there may often cut through the thin veneer of sediments into basement rock. Further downstream, groundwater baseflows to rivers may, however, subsequently return and increase across the plain. The Linthipe River BFI data (Figure 3) referred to earlier support this conceptualization. Larger rivers rising in the highland often continually flow, albeit at much reduced rates in the dry season, and most smaller streams exhibit ephemeral intermittent flow and cease to flow in the dry season [33]. For instance, Walters (1972) [31] observes that "many streams die away into the sandy alluvium before reaching the lake".

The Lilongwe-Linthipe system approaches perennial flow due to the extensive catchment upstream, but it should be noted that flows, on average, cease for around 25 days annually [31]. Similarly, Sefe's (1988) [45] aforementioned low-flow analysis of the Linthipe (gauge 4B1) confirms that no-flow conditions occur in the dry season around the Salima lakeshore plain. Intermittency is ascribed to the remote upland-dambo primary sources of flow to the river and the likelihood of groundwater levels being beneath river levels, especially in the permeable alluvial deposits, extensive around Salima, that build during flood events. Moreover, influent river conditions of good quality water, causing locally improved groundwater quality (lower TDS), were observed here by Smith-Carington and Chilton (1983) [33]. That river leakage, combined with increased precipitation (1400 $\mathrm{mm}$ pa in the lakeshore Linthipe estuary area compared to $800-1000 \mathrm{~mm}$ pa in the Lilongwe Plain), [48], were predicted by Smith-Carington and Chilton [33] to cause an increased groundwater recharge of fresh water and further counteract the typical progression of increased salinity by mineral solution in groundwater slowly migrating towards the lakeshore. The heterogeneous hydrochemical water type and TDS data in this area display such trends, as per our earlier discussion of Figure 6 (data points in the north east). These process complexities, adding to the evaporative enrichment of the shallower groundwater and the Lake Malawi interaction-flooding, are supported by the increased variation in hydrochemical type and isotope signatures apparent near the lakeshore area, where most outlier data tend to occur. The significant range in the processes contributing to isotope signature variations is apparent in Figure 12. It is an area deserving of more focused study.

\subsection{Lake Malawi-Groundwater Interaction}

Whist hydraulic gradients towards Lake Malawi in the low-relief lakeshore plains are minimal at $0.001-0.01$, transmissivity estimates from pumping tests in the Salima district area of $100-300 \mathrm{~m}^{2} / \mathrm{d}$ cause the estimated underflow in the alluvium and discharge to the lake to still be significant; discharge was calculated at around $0.13-0.38 \times 10^{6} \mathrm{~m}^{3}$ annually per kilometer of shoreline (for a gradient of 0.0035) [33]. Some wet season flow reversal in the local vicinity of the lake shoreline is likely, as more rapidly responding lake levels can become 1-2 $\mathrm{m}$ higher than the groundwater, thereby driving temporary storage of invading lake water into the alluvial aquifer. However, such invaded water may later return to the lake upon the seasonal re-establishment of gradients towards Lake Malawi. Smith-Carington and Chilton (1983) [33] calculate storage of invading lake water equivalent to around $10 \%$ of the groundwater discharge-to-lake volume (calculated above), with the invasion estimated to reach just $500 \mathrm{~m}$ inland. Hence, although exerting a relatively small influence volumetrically, this may generate complexity in near-shoreline groundwater hydrochemical and isotopic signatures. The complexity of the isotope signatures in the lakeshore plain-Lake Malawi approach and the dry-wet season isotope contrasts observed are supportive of the above dynamic interactions, together with the large flood event and groundwater evaporative processes occurring. Again, more targeted high resolution spatial and temporal studies would be necessary to isolate details of individual processes and their interactions. 


\section{Discussion and Conclusions}

\subsection{Catchment Management Implications}

This study has successfully used stable isotope tracers to establish an isotopic baselinehydrochemical understanding for an important Lake Malawi catchment. The catchment includes its capital city Lilongwe, but also extensive rural-agricultural areas with representative coverage of the divers Rift Valley physiography. The study has reinforced the conceptualisation of water resource occurrence and provenance in what has proven to be a hydrological-hydrogeological complex scenario, but one that can reasonably be assumed to be representative of a Rift Valley catchment. This is the first published study to use an isotope facility developed in-house within Malawi, that has not relied upon the export of water samples for analysis or interpretation abroad. The study endorses that isotope tools may offer increased insight and/or confirmations, including about the nature and type of water resources available, not just in Malawi, but in any country. Making such tools more widely available to developing countries would allow a more robust delivery of SDG 6 and sustained future IWRM.

The complexities associated with groundwater-surface-water interactions and their diverse occurrence in the study area is a notable feature. These include: delayed, slow-release of water from dambo, that may critically sustain system flows in the dry season; the occurrence of influent and effluent river reaches in various parts of the plateau and lakeshore plains, some of which may exhibit seasonal reversals; and a complexity of processes occurring at the Lake Malawi-foreshore interface where, again, the seasonal reversal of groundwater and lake water flows may occur. Resolving the detail of these and other processes will require more focused, higher spatial/temporal resolution studies, to which isotope tools may be significant. It is especially important that an increased range of tracer isotope and chemical (e.g., CFCs) forensic tools become more available, building upon the stable isotope base achieved. In Malawi, these need to be underpinned by expansion of the fledgling isotope precipitation sampling station network, and continued monitoring, to generate LMWL for all 'Managed Catchments'. This is important, recognizing the wide variation evident in precipitation isotopic composition that is attributable to different rain-bearing systems nationally, alongside more local geographic controls.

Improved isotopic characterization is warranted for the various aquifer types and specific flow pathways, especially those that may serve as a pollutant linkage and pose health risks. For instance, it could be used to assess fault-assisted flows to the surface of deep-sourced groundwater that may drive some of Malawi's salinity [49], fluoride [50] and arsenic [51] risks. Expanding isotope capacity to include tritium (and helium), nitrogen-15 and carbon isotope fingerprinting may help document salinity provenance [52]. The development of isotope capacity and tracer range may likewise assist in the attribution of land-surface sources of groundwater pollution, which are expected to grow-arising, for instance, from agriculture and basic sanitation provision (notably pit latrines) — that have been challenging to attribute in Malawi based on hydrochemical data alone [53]. Furthermore, as IWRM will become increasingly vital, isotopes may assist understanding of the probable mixing of water source types that may occur in, e.g., water transfer, wastewater injection and irrigation schemes.

The influence of land use and climate change on system water resources is of particular concern due to the water system connectivity evident herein and expected in other Rift Valley catchments. It is clear that changes in the management of land around dambo may have significant knock-on influences far downstream, due to its significance as a sustaining dry-season river source. Concerns surrounding increasing agricultural activity around dambo, recognized by Smith-Carington and Chilton (1983) [33] over 35 years, ago remain very valid today. These include the increased channeling of flows, enhanced erosion, higher flood peaks and earlier cessation of dry-season flows. The strategic need to "promote management systems and technologies that protect fragile lands" that include "dambo" areas "is recognized in Malawi's current National Agricultural Investment Plan" [54]. Similarly, the knock-on effects of extensive deforestation across Malawi in the last decade (and longer) upon groundwater and surface water resources and ecosystem services is already a significant concern, and has been observed 
to lead to increased occurrence in Malawi of flooding and extreme low-flows that are predicted to persist [25]. Isotopic tools may help improve diagnosis of water-system linkages to furnish the optimal response to deforestation concerns.

\subsection{Implication for Policy Implementation}

In due course, from this study and its ongoing companion (catchment) studies, the underpinning of Malawian policy implementation is expected on several fronts, important agenda items including:

1. The Government of Malawi should evaluate the sustainability of current catchment management plans to verify if they meet national targets for SDG 6;

2. The Government of Malawi should delineate groundwater recharge zones and protect them from degradation;

3. The Government of Malawi should arrest (and reverse) deforestation in order to sustain groundwater resources and prolong dry-season river baseflows;

4. The Government of Malawi should revisit water-budget calculations (e.g., Water Budget for Lake Malawi) in light of the improved conceptualization and quantification of groundwater contribution to surface water ecosystem services and surface-water resource volumes;

5. The Government of Malawi should prioritize the protection of groundwater resources from pollution;

6. The Government of Malawi should conduct a targeted study of leakage from aging dams in order to enhance dam-safety (e.g., Kamuzu Dam I and II);

7. The Government of Malawi should be part of a network of partners with critical mass to confront today's groundwater issues for the benefit of the present and future generations, by conducting research and building capacity in all aspects in the areas necessary to achieve IWRM;

8. Climate Change is likely to intensify our dependence on groundwater, so the need for increased access to water isotope tracer tools for technical solutions is becoming critical. There is a need to conjunctively manage the surface water and groundwater resources that include transboundary aquifers, as, without coherent policies, attaining many of the UN's Sustainable Development Goals will be a challenge.

Supplementary Materials: The following are available online at http://www.mdpi.com/2073-4441/11/12/2600/s1, Tables S1-S3 providing statistical summaries of isotopic composition of local precipitation, groundwater and surface water sampled, and the details of the field survey sampling sites and the isotope and hydrochemical datasets obtained.

Author Contributions: Conceptualization, L.C.B., M.O.R., R.M.K., A.S.K.Z.; methodology, L.C.B., M.O.R. and R.M.K.; validation, L.C.B., A.S.K.Z.; formal analysis, L.C.B., M.O.R., L.K. and C.C.K.; investigation, L.C.B., M.O.R., L.K., A.S.K.Z.; resources, L.C.B., A.S.K.Z., P.P.; data curation, L.C.B., A.S.K.Z. and L.K.; writing-original draft preparation, L.C.B. and M.O.R.; writing-review and editing, M.O.R., L.C.B., L.K., R.M.K., G.C., P.P., M.N. (Macpherson Nkhata) and M.N. (Muthi Nhlema); visualization, L.C.B., M.O.R., C.K. and L.K.; supervision, R.M.K., M.O.R., P.P., P.M., S.K.; project administration, R.M.K., S.K., P.P. and M.N. (Muthi Nhlema); funding acquisition, R.M.K., S.K., P.M. and P.P.

Funding: We gratefully acknowledge the funding by the International Atomic Energy Agency (IAEA) under the Malawi Technical Cooperation (TC) Projects' grants (MLW/7/001: MLW/7/002/MLW/7/003), awarded to the Government of Malawi (Department of Water Resources in the Ministry of Agriculture, Irrigation and Water Development). We also acknowledge the financial contribution we received from the Government of Malawi and the Scottish Government Climate Justice Fund-Water Futures Programme research grant HN-CJF-03 awarded to the University of Strathclyde.

Acknowledgments: We acknowledge the technical and administrative support rendered to us by the BASEflow organization based in Malawi.

Conflicts of Interest: The authors declare no conflict of interest. 


\section{References}

1. Attandoh, N.; Yidana, S.M.; Abdul-Samed, A.; Sakyi, P.A.; Banoeng-Yakubo, B.; Nude, P.M. Conceptualization of the hydrogeological system of some sedimentary aquifers in Savelugu-Nanton and surrounding areas, Northern Ghana. Hydrol. Process. 2013, 27, 1664-1676. [CrossRef]

2. Yidana, S. The Stable Isotope Characteristics of Groundwater in the Voltaian Basin-An Evaluation of the Role of Meteoric Recharge in the Basin. J. Hydrosci. Hydraul. Eng. 2013, 2. [CrossRef]

3. Han, Z.; Shi, X.; Jia, K.; Sun, B.; Zhao, S.; Fu, C. Determining the Discharge and Recharge Relationships between Lake and Groundwater in Lake Hulun Using Hydrogen and Oxygen Isotopes and Chloride Ions. Water 2019, 11, 264. [CrossRef]

4. Boronina, A.; Renard, P.; Balderer, W.; Stichler, W. Study of stable isotopes in the Kouris catchment (Cyprus): Description of the regional groundwater flow. J. Hydrol. 2004, 308, 214-226. [CrossRef]

5. Kalin, R.M. Radiocarbon Dating of Groundwater Systems. In Environmental Tracers in Subsurface Hydrology; Cook, P.G., Herczeg, A.L., Eds.; Springer: Boston, MA, USA, 2000; pp. 111-144. [CrossRef]

6. Rodgers, P.J.; Soulsby, C.; Waldron, S.; Tetzlaff, D. Using Stable Isotope Tracers to Assess Hydrological Flow Paths, Residence Times and Landscape Influences in a Nested Mesoscale Catchment. Hydrol. Earth Syst. Sci. Discuss. 2005, 9, 139-155. [CrossRef]

7. Sidibé, A.M.; Lin, X.; Koné, S. Assessing Groundwater Mineralization Process, Quality, and Isotopic Recharge Origin in the Sahel Region in Africa. Water 2019, 11, 789. [CrossRef]

8. González-Trinidad, J.; Pacheco-Guerrero, A.; Júnez-Ferreira, H.; Bautista-Capetillo, C.; Hernández-Antonio, A. Identifying groundwater recharge sites through environmental stable isotopes in an alluvial aquifer. Water 2017, 9, 569. [CrossRef]

9. Kumar, U.S.; Hadi, K. Futuristic isotope hydrology in the Gulf region. Appl. Water Sci. 2018, 8. [CrossRef]

10. Hameed, A.S.; Resmi, T.R.; Suraj, S.; Unnikrishnan Warrier, C.; Sudheesh, M.; Deshpande, R.D. Isotopic characterization and mass balance reveals groundwater recharge pattern in Chaliyar river basin, Kerala, India. J. Hydrol. Reg. Stud. 2015, 4A, 48-58. [CrossRef]

11. Zhao, L.J.; Eastoe, C.J.; Liu, X.H.; Wang, L.X.; Wang, N.L.; Xie, C.; Song, Y.X. Origin and residence time of groundwater based on stable and radioactive isotopes in the Heihe River Basin, north western China. J. Hydrol. Reg. Stud. 2018, 18, 31-49. [CrossRef]

12. Barbieri, M. Isotopes in Hydrology and Hydrogeology. Water 2019, 11, 291. [CrossRef]

13. Kalin, R.M. Basic concepts and formulations for isotope-geochemical process investigations, procedures and methodologies of geochemical modelling of groundwater systems. In Manual on Mathematical Models in Isotope Hydrology; Yurtsever, Y., Ed.; IAEA: Vienna, Austria, 1995; Volume 910, pp. 155-206.

14. Kalin, R.M.; Long, A. Application of hydrogeochemical modelling for validation of hydrologic flow modelling in the Tucson Basin Aquifer, Arizona, USA. In Mathematical Models and Their Applications to Isotope Studies in Groundwater Hydrology; IAEA: Vienna, Austria, 1994; pp. 209-254.

15. Verhagen, B.T. Isotope hydrology and its impact in the developing world. J. Radioanal. Nucl. Chem. 2003, 257, 17-26. [CrossRef]

16. IAEA (International Atomic Energy Agency). Atlas of Isotope Hydrology-Africa; IAEA: Vienna, Austria, 2007; pp. 1-13. Available online: https://www-pub.iaea.org/MTCD/Publications/PDF/P1302_web.pdf (accessed on 10 September 2019).

17. Oiro, S.; Comte, J.-C.; Soulsby, C.; Walraevens, K. Using stable water isotopes to identify spatio-temporal controls on groundwater recharge in two contrasting East African aquifer systems. Hydrol. Sci. J. 2018, 63, 862-877. [CrossRef]

18. Monjerezi, M.; Vogt, R.D.; Aagaard, P.; Saka, J.D.K. Using $\delta^{87} \mathrm{Sr} / \delta^{86} \mathrm{Sr}, \delta^{18} \mathrm{O}$ and $\delta^{2} \mathrm{H}$ isotope data along with major chemistry composition to assess groundwater salinization in lower Shire River Valley, Malawi. Appl. Geochem. 2011, 26, 2201-2214. [CrossRef]

19. Macdonald, A.M.; Bonsor, H.C.; O'Dochartaigh, B.E.; Taylor, R.G. Quantitative maps of groundwater resources in Africa. Environ. Res. Lett. 2012, 7, 024009. [CrossRef]

20. Truslove, J.P.; Miller, A.V.M.; Mannix, N.; Nhlema, M.; Rivett, M.O.; Coulson, A.B.; Mleta, P.; Kalin, R.M. Understanding the functionality and burden on decentralised rural water supply: Influence of Millennium Development Goal 7c coverage targets. Water 2019, 11, 494. [CrossRef] 
21. Kalin, R.M.; Mwanamveka, J.; Coulson, A.B.; Robertson, D.J.C.; Clark, H.; Rathjen, J.; Rivett, M.O. Stranded Assets as a key concept to guide investment strategies for Sustainable Development Goal 6. Water 2019, 11, 702. [CrossRef]

22. MoAIWD (Ministry of Agriculture, Irrigation and Water Development). Irrigation and Cash Crops for a Better Life-The Shire Valley Irrigation Project (SVIP). 2016. Available online: http://www.shirebasin.mw/ index.php?option=com_sppagebuilder\&view=page\&id=22\&Itemid=518 (accessed on 8 October 2019).

23. Government of Malawi. Malawi Hydrogeological Atlas; Ministry of Agriculture, Irrigation and Water Development: Lilongwe, Malawi, 2019.

24. Coulibaly, J.Y.; Mbow, C.; Sileshi, G.W.; Beedy, T.; Kundhlande, G.; Musau, J. Mapping vulnerability to climate change in Malawi: Spatial and social differentiation in the Shire River Basin. Am. J. Clim. Chang. 2015, 4, 282-294. [CrossRef]

25. Kambombe, O.; Odongo, V.; Mutual, B.; Wambua, R. Impact of climate variability and land use change on streamflow in lake Chilwa basin, Malawi. Int. J. Hydrol. 2018, 2, 364-370.

26. Adhikari, U.; Nejadhashemi, A.P. Impacts of Climate Change on Water Resources in Malawi. J. Hydrol. Eng. 2016, 21, 05016026. [CrossRef]

27. World Food Program. WFP Malawi Country Brief (July 2018). Available online: https://docs.wfp.org/api/ documents/WFP-0000073745/download/?_ga=2.159010418.932160188.1536781160-1100854252.1536781160 (accessed on 8 October 2019).

28. Kelly, L.; Kalin, R.M.; Bertram, D.; Kanjaye, M.; Nkhata, M.; Sibande, H. Quantification of Temporal Variations in Base Flow Index Using Sporadic River Data: Application to the Bua Catchment, Malawi. Water 2019, 11, 901. [CrossRef]

29. Walter, M.J. The Geology of the Lilongwe-Dowa Area; Malawi Government: Zomba, Malawi, 1972.

30. Thatcher, E.C.; Walter, M.J. The Geology of the South Lilongze Plain and Dzalanyama Range; Malawi Government: Zomba, Malawi, 1968.

31. Walter, M.J. The Geology of the Salima-Mvera Mission Area; Malawi Government: Zomba, Malawi, 1972.

32. BGS (British Geological Survey). Groundwater Quality: Malawi. British Geological Survey/WaterAid Country Information Sheet. Available online: https://www.bgs.ac.uk/downloads/start.cfm?id=1283 (accessed on 8 October 2019).

33. Smith-Carrington, A.K.; Chilton, P.J. Groundwater Resources of Malawi. Overseas Development Administration Institute of Geological Sciences, 1983. Available online: http://resources.bgs.ac.uk/sadcreports/ malawi1983smithcarringtonmalawigwresources.pdf (accessed on 8 October 2019).

34. Republic of Malawi, Ministry of Agriculture, Irrigation and Water Development. Project for National Water Resources Master Plan in the Republic of Malawi-Final Report; Volume II: Main Report; Ministry of Agriculture, Irrigation and Water Development: Lilongwe, Malawi, 2014.

35. Chavula, G.M.S. Malawi. In Groundwater Availability and Use in Sub-Saharan Africa: A Review of Fifteen Countries; Pavelic, P., Giordano, M., Keraita, B., Ramesh, V., Rao, T., Eds.; International Water Management Institute: Colombo, Sri Lanka, 2012; Available online: http://www.iwmi.cgiar.org/Publications/Books/PDF/ groundwater_availability_and_use_in_sub-saharan_africa_a_review_of_15_countries.pdf (accessed on 15 October 2019).

36. Peel, M.C.; Finlayson, B.L.; McMahon, T.A. Updated world map of the Köppen-Geiger climate classification. Hydrol. Earth Syst. Sci. 2007, 11, 1633-1644. [CrossRef]

37. IAEA/GNIP (International Atomic Energy Agency/Global Network of Isotopes in Precipitation). Precipitation Sampling Guide; International Atomic Energy Agency: Vienna, Austria, 2014. Available online: http: //www-naweb.iaea.org/napc/ih/IHS_resources_gnip.html (accessed on 5 November 2019).

38. IAEA/WMO (International Atomic Energy Agency/World Meteorological Organization). Global Network of Isotopes in Precipitation. The GNIP Database; International Atomic Energy Agency: Vienna, Austria, 2019. Available online: http://www-naweb.iaea.org/napc/ih/IHS_resources_gnip.html (accessed on 15 April 2019).

39. Boschetti, T.; Cifuentes, J.; Iacumin, P.; Selmo, E. Local Meteoric Water Line of Northern Chile ( $\left.18^{\circ} \mathrm{S}-30^{\circ} \mathrm{S}\right)$ : An Application of Error-in-Variables Regression to the Oxygen and Hydrogen Stable Isotope Ratio of Precipitation. Water 2019, 11, 791. [CrossRef] 
40. IAEA (International Atomic Energy Agency). Laser Spectroscopic Analysis of Liquid Water Samples for Stable Hydrogen and Oxygen Isotopes; Training Course Series No. 35; International Atomic Energy Agency: Vienna, Austria, 2009. Available online: https://www.iaea.org/publications/8195/laser-spectroscopic-analysis-ofliquid-water-samples-for-stable-hydrogen-and-oxygen-isotopes (accessed on 8 November 2019).

41. APHA (American Public Health Association). Standard Methods for the Examination of Water and Wastewater; American Public Health Association (APHA): Washington, DC, USA, 2005.

42. International Commission on Groundwater. Surface Water and Groundwater Interaction. In A Contribution to the International Hydrological Programme; The United Nations Educational, Scientific and Cultural Organization (UNESCO): Paris, France, 1980.

43. Tallaksen, L.M.; Van Lanen, H.A. Hydrological Drought: Processes and Estimation Methods for Streamflow and Groundwater; Elsevier Science B.V.: Amsterdam, The Netherlands, 2004; p. 579. Available online: http://europeandroughtcentre.com/software/software-from-textbook-hydrologicaldrought-tallaksen-and-van-lanen-2004/ (accessed on 8 November 2019).

44. Institute of Hydrology. Low Flow Studies-Report 3; Institute of Hydrology: Wallingford, UK, 1980.

45. Sefe, F.T.K. Some aspects of the hydrology of on-day annual minimum low flows of Malawian rivers. Hydrol. Process. 1988, 2, 75-91. [CrossRef]

46. Craig, H. Isotopic variations in meteoric waters. Science 1961, 133, 1702-1703. [CrossRef]

47. Gonfiantini, R.; Zuppi, G.M.; Eccles, D.H.; Ferro, W. Isotope investigation of Lake Malawi. In Isotopes in Lake Studies; International Atomic Energy Agency (IAEA): Vienna, Austria, 1979.

48. Mkanda, F.X. Soil Erosion, Anthropogenic Effects, and Interrelations between Soil Conservation, Climate Change and the Biodiversity of Lake Malawi/Niassa/Nyasa. Ph.D. Thesis, University of Manitoba, Winnpeg, MB, Canada, 2000.

49. Rivett, M.O.; Budimir, L.; Mannix, N.; Miller, A.V.M.; Addison, M.J.; Moyo, P.; Wanangwa, G.J.; Phiri, O.L.; Songola, C.E.; Nhlema, M.; et al. Responding to Salinity in a Rural African Alluvial Valley Aquifer System: To Boldly Go beyond the World of Hand-Pumped Groundwater Supply? Sci. Total Environ. 2019, 653, 1005-1024. [CrossRef]

50. Addison, M.J.; Rivett, M.O.; Robinson, H.; Fraser, A.; Miller, A.V.M.; Phiri, P.; Mleta, P.; Kalin, R.M. Fluoride occurrence in the lower East African Rift System, Southern Malawi. Sci. Total Environ. 2019. under review.

51. Rivett, M.O.; Robinson, H.L.; Wild, L.M.; Melville, J.; McGrath, L.; Phiri, P.; Flink, J.; Wanangwa, G.J.; Mleta, P.; MacLeod, S.S.P.; et al. Arsenic occurrence in Malawi groundwater. J. Appl. Sci. Environ. Manag. 2018, 22, 1807-1816. [CrossRef]

52. Chowdhury, A.H.; Scanlon, B.R.; Reedy, R.C.; Young, S. Fingerprinting groundwater salinity sources in the Gulf Coast Aquifer System, USA. Hydrogeol. J. 2018, 26, 197-213. [CrossRef]

53. Back, J.O.; Rivett, M.O.; Hinz, L.B.; Mackay, N.; Wanangwa, G.J.; Phiri, O.L.; Songolo, C.E.; Thomas, M.A.S.; Kumwenda, S.; Nhlema, M.; et al. Risk assessment to groundwater of pit latrine rural sanitation policy in developing country settings. Sci. Total Environ. 2018, 613C-614C, 592-610. [CrossRef]

54. Government of Malawi. National Agricultural Investment Plan-Prioritised and Coordinated Agricultural Transformation Plan for Malawi: FY 2017/18-2022/23. 2018. Available online: https://www.scotland-malawipartnership.org/files/9815/3113/0121/National_Agicultural_Investment_ Plan_2018_Final_Signed.pdf (accessed on 8 October 2019).

(C) 2019 by the authors. Licensee MDPI, Basel, Switzerland. This article is an open access article distributed under the terms and conditions of the Creative Commons Attribution (CC BY) license (http://creativecommons.org/licenses/by/4.0/). 